\title{
Micro Small Medium Enterprises (MSMEs) Survival Ability in Pandemic Covid 19 Era: Integration of Technology, Organization, and Environment Analysis
}

\author{
Yusvita Nena Arinta ${ }^{1}$, Rifda Nabila ${ }^{2}$, Iskandar ${ }^{3}$, Nafis Irkhamni ${ }^{4}$, Ubaedul Mustofa ${ }^{5}$ \\ \{nena@iainsalatiga.ac.id ${ }^{1}$, rifdanabila@iainsalatiga.ac.id², iskandarchang@iainsalatiga.ac.id ${ }^{3}$, \\ nafisirkhamni@gmail.com ${ }^{4}$,ubaed_almustafa@mail.unnes.ac.id ${ }^{5}$ \} \\ Faculty of Islamic Economics and Business, IAIN Salatiga - Indonesia ${ }^{1,2,3,4}$ \\ Faculty of Economy, Semarang State University-Indonesia ${ }^{5}$
}

\begin{abstract}
The Pandemic of COVID-19 has economic, social and political implications not only for large countries but also for almost all countries in the world. Indonesia is one of the countries affected mainly from the economic side, which is dominated by Micro, Small and Medium Enterprises (MSMEs). The economic slowdown occurred, requires companies to have a clear understanding of the crisis occurred to ensure they more quickly adapt to the situation and minimize the company's losses. One way is to apply digital technology in the face of the COVID-19 Pandemic. The application of digital technology can increase the productivity and performance of MSMEs. In this research, the application of digital technology is explained using a TOE framework that combines aspects of technology, organization, and environment.
\end{abstract}

Keywords: MSMEs, Pandemic, Technological, Organizational, Environmental.

\section{Introduction}

Growth and development of Micro, Small and Medium Enterprises (MSMEs) are the main indicators of productive business that affect micro and macroeconomic development in various economic sectors in Indonesia [1][2]. Data reported by the Ministry of Cooperatives and Small and Medium Enterprises (KemenkopUMKM) in 2018, MSMEs were able to absorb 97\% of the workforce of 116,978,631 workers from a total of 99\% of economic workers and MSMEs contributed $60.3 \%$ of total gross domestic product (GDP) Indonesia [3]. Micro, Small Medium Enterprises as the main priority with the role of strategy in the revival of development during the crisis in 1999. This is evidence that MSMEs can survive compared to other sectors that are shaking amid the current crisis shocks [4].

Currently, the world is shaken by a global crisis stemming from the corona outbreak pandemic (COVID 19), which has a significant effect on the order of various economic sectors in the world. Crisis events like this are a risk of a business that cannot be predicted in advance [5]. MSMEs faced with the ability to adapt to meet the challenges of whether they can just survive or remain on the target of sustainable profit or weaken with the situation [6]. The impact of this Pandemic is still being felt massively by all business sectors in the world. Changes occur in the order of business culture, environment, and market demand. How can it not be a pandemic due to the real transmission of the novel coronavirus infection disease (COVID-19) which requires independent isolation at home, social distancing, not being in the crowd causing paralysis of the global economy? Efforts to prevent the speed of the COVID-19 virus become a 
barrier to business continuity, including the cessation of the supply chain, reduced business operations, and minimal human resources [7]. The implication is an excellent impact on MSMEs because capital, assets and range of productivity are relatively smaller than in large scale companies [2].

A survey conducted by the Indonesian Institute of Sciences (LIPI) through the Center for Economic Research (P2E) showed data on MSME sales decreased by $94,69 \%$ due to this invisible virus. Restructuring of MSMEs needs to be done considering that the impact of the corona outbreak pandemic has made the cost structure increase so that MSMEs are more vulnerable to collapse. From the LIPI survey, which involved 679 valid respondents whose main livelihood as business operators showed the price of raw material costs increased $45,07 \%$ due to the lockdown status of the area that broke the chain. A decrease in labour costs was resulting in an economic recession due to rising unemployment. Other and general costs experienced a significant jump up to $44,33 \%$. For transportation costs, the surge is in the range of $23,41 \%$. The decline in the performance of MSMEs also impacts on the reduction in people's purchasing power. Research conducted by the Norbotten Chamber of Commerce shows that $70 \%$ of MSMEs affected by the Covid pandemic have taken policy steps for cost efficiency.

The fact shows the vulnerability of MSMEs in times of crisis like this makes the challenges of existence for MSMEs. Exploration presents new opportunities as a challenge due to the size and flexibility of MSMEs in the effort to develop strategies for sustainable business operations [8]. Strategic efficiency is based on company capability. MSMEs have broader revival and economic implications [9]. This crisis is the right moment to change the mindset; therefore, MSMEs can survive amid a global crisis due to the COVID-19 Pandemic. The opportunity for MSMEs to take the business's attention when large-scale global business people also experience inequality. Improving the quality of products and services as well as the development or adaptation of various strategies for MSME product and service offerings [10]. Small businesses are the fastest recovery media in the economic sector reform throughout the world [11]. Countries show the role of MSMEs as an engine of growth in various regions of the world. Economic recovery is fast because it absorbs labour, tax stability, risk diversification, launching innovative products, and the adoption of new technologies [1].

The business of MSME can struggle to carry out tracing for customers to carry out for product development strategy and service improvement with consideration of efficiency according to their capacity. The development or adaptation of the right MSME strategy can draw business attention so that MSMEs are not worrying about unpredictable crises. MSME core competencies to achieve survival and growth by involving a variety of knowledge and information, creating innovation. The way out this crisis as demand for a force to adapt to change the spread of strategic expertise [12]. UMKM actors can survive in times of crisis so that it becomes a phonation for economic revival. Strategies that need to develop in financial knowledge are the power to mix comprehensive source sharing between technology, an organization with management of human and cultural resources, and the environment [13]. The framework influences business strategy innovation in the integration of technology development, organizational structure, and the surrounding environment [14]. The innovation approach using technology is an appropriate technique in dealing with the COVID-19 pandemic crisis [10]. This innovation shows that technological innovation is a significant role in the sustainability of business continuity, including MSMEs.

This research is a reference material for MSME actors as a strategic solution to the survival of MSMEs in the Covid 19 pandemic era with all the limitations that include. Efforts to increase understanding through breakthroughs in the integration of organizational and environmental technology. An in-depth understanding of the unique characteristics of this crisis attack can help 
MSMEs to survive. Of course, the success of MSMEs cannot be separated from the role of the government as a policy maker that can reduce the rate of spread of the virus but not weaken the economy.

\section{Literatur Review}

In the current COVID-19 Pandemic, the resilience of MSMEs as an economic stimulus can maintain its selling power well. The persistence of selling power has an impact on all aspects of the buying life cycle, the supply chain, employment. Using an integrated approach between technology, organization and the environment, it can develop the concept of a framework in the MSME resilience process during this pandemic situation. However, economic stimulus is still needed from the government as a policymaker that supports the sustainability of MSME businesses in addition to financial restructuring. In that way, the MSMEs can carry out business in a strategic manner. By adopting the integration of technology, organization and environment in detail, the SMEs can identify sophisticated customer needs indicators. Improvement of digital technology with management support that promotes cultural centres and environmental harmony contexts can provide opportunities and potential for MSMEs. The Environmental Organizational Technology Framework (TOE, Technology-Organization-Environment) describes a research model that has the power of theory and drives the development of research on innovation and adoption of a business [15]. In the TOE framework approach there are 3 components used for the adoption of development and innovation, namely the technology sector, organizational concepts and environmental concepts. The concept of technology explains renewability, updates that are relevant to the company. The organizational concept leads to the quality of human resource management, organizational culture. The concept of the environment leads to the scope where the MSMEs carry out their operations while continuing to preserve the environment and competitors [16]. The TOE framework underlines three components of thought, the adoption component - leader characteristics including internal characteristics, (complexity, centralization, interconnectedness, formalization, leeway and organizational size); and external characteristics (system openness). Leaders adopt an understanding of internal and external characteristics such as centralization, formalization, complexity, structural and organization.

The second conceptual framework is known as a technology framework which is a factor of technological innovation and adoption. It is used both external and internal attributes of the organization and aspects related to technology [16]. Innovations that have been carried out empirical studies are in the field of Electronic Data Interchange (EDI) or system adoption [17], the internet approach which is becoming a media that is widely used by MSMEs can be adapted to the current pandemic conditions, where existing conditions demand to always stay at home. The presence of e-commerce can be a technological approach used by MSMEs to be able to survive in a COVID-19 pandemic situation [18]. And the last concept of thought is about environmental care. The MSMEs continue to run the business while still paying attention to the surrounding environment.

This study uses a TOE (Technology-Organization-Environment) analysis because it illustrates the concept of an appropriate analytical framework in order to provide the adoption and assimilation of various types of innovations. Consistent empirical support, and wide application potential in various studies. In the context of applying technology, it has a large 
impact on MSMEs [19]. Factors that influence the success of innovation of technology are the relative advantages, complexity, traceability, ability of observation and trials [20]. The comparative advantage is identified by the degree to which innovation is considered successful from previous changes [21]. Adaptation through technology will incur high costs in certain periods but will reduce subsequent costs so as not to cause slank cots in the future [22]. The MSMEs are required to adapt to the current situation, a technological approach by taking into account the demand during a pandemic as it is today. Technology with the concept of making it easier and closer to the market is felt to be able to lift the SMEs overburdened after the formation of COVID-19. Complexity as a driver of innovation as a solution that provides convenience as a solution to difficulties and complex. Successful implementation of technology will create certainty and minimize the ratio [20]. Trialability or ability to test as "an innovation that can be tried with limited" [21]. The trial becomes relevant to the concept of adoption of technological innovation approaches. Businesses will soon find out the shortcomings and weaknesses of the technology applied. While the ability to observe the extent to which others see the results of an innovation. What are the breakthroughs and uniqueness of technological innovation, so that the MSMEs become attractors of market interest? In this technological approach, MSME players can use digital marketing by utilizing social media to claim their consumers. Besides ecommerce, which must be used in this pandemic era, so that MSMEs can survive. the higher the level of technological competence, the higher the ability to adopt e-commerce.

The organization as an internal factor that supports the going concern of MSMEs. Top management support, organizational readiness, experience and size are indicators that influence the organization. Top management supporting is one of the best predictors that can mitigate change stimulus by communicating and reinforcing values through an articulated vision for the organization [23]. The upper management strongly supports innovation and adoption of relevant new technologies, because policy decisions rest with the central management authority [24]. Organizational readiness is a term for the organization's availability of the resources needed, measuring whether a company has the capacity and the management of financial resources.u The third concept of the TOE is the environment, which explains the competition in which MSMEs run their business competitively, trading partners, social-cultural arrangements and government support through policy [25]. Therefore by mastering the concept of the environment, the MSMEs can avoid which are the obstacles and supporting factors of their business. Fostering good relationships with customers is also part of a good customer relationship.

the research question can be explained through the scheme below

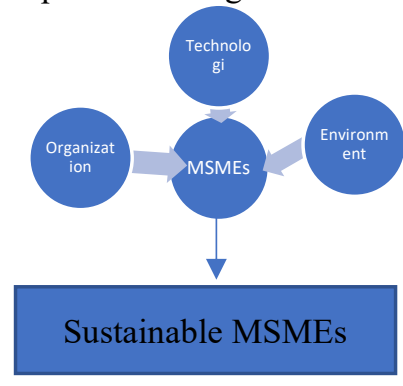

Fig.1. research question

\section{Small and Medium Enterprises (SMEs) During Pandemic}


The COVID-19 Pandemic has negative implications for the domestic economy, such as declining public purchasing power, declining corporate performance, threats from the banking and financial sectors, and the existence of MSMEs. This situation presents challenges as well as opportunities for MSME businesses to maintain their existence. SMEs are encouraged to utilize digital platforms to develop their businesses amid the new order. This is in line with changes in community behavior driven by the COVID-19 Pandemic. The demand to implement health protocols to prevent transmission of COVID-19 causes people to become more digital (digital life style).

A strong business plan can ensure the sustainability of all types of businesses. According to the World Bank, MSMEs that represent almost $90 \%$ of businesses around the world, showed the importance of the existence of MSMEs in the economy of a country. The COVID-19 Pandemic is an extraordinary situation that tests the durability and stability of MSMEs. MSMEs need to innovate and be creative according to the needs of consumers. Innovation and creation can be performed, starting from simple things that have market opportunities. Besides, SMEs can also collaborate with many parties so that they can get better input related to innovation and service to consumers.

Utilization of digital technology can be a solution to the problems of the distribution process that are experiencing pressure due to a pandemic.

\section{Method}

Judging from the type of data, the research approach used in this study is a qualitative approach. The type of research approach is descriptive. Descriptive research is research that seeks to find solutions to existing problems based on data. This type of qualitative descriptive research used in this study is intended to obtain information about the application of digital technology in MSMEs.

\section{Technological, Organizational, and Environmental for Sustainable SMEs}

The model developed by Tornatzky and Fleisher [16] about the relationship of technology, organization and environment is a technology acceptance model at the company level, which discusses three major influences on the potential for technology acceptance or technology adoption.

\section{a. Technological}

The technology context refers to internal technology and external technology, including the processes and equipment used. This context also describes new technology and old technology that is considered relevant to be used by companies. There are three factors of innovation that are most often studied in the technology innovation literature [26], including:

\section{Relative Advantage.}

Relative advantage is a technological factor that is perceived to be of a more significant benefit than the technology previously used [21]. The use of online marketplaces that increase the opportunities of MSMEs to expand the target market and make the business being run more reliable. Also, the use of e-payment such as Flazz, OVO, T-Cash, etc. can also provide many benefits, including promos obtained by users and e-payment providers, in a faster and practical payment process, as well as security guarantees and guarantees in payments.

2. Compatibility 
is the extent to which an innovation is considered consistent with existing socio-cultural values and beliefs, experience and the need for companies to adopt potential technologies [21]. The values that are felt by MSMEs and consumers in applying digital technology are the ease in conducting transactions, both from offering goods, selecting goods, paying and shipping goods. The innovation offered is a growing trend in society that is starting to switch to using an online marketplace.

\section{Complexity}

Complexity is the level of difficulty in understanding and finding technological innovations [21], [27]. The difficulty of MSMEs in implementing digital technology is the need for human resources capable of mastering technology, getting prospective customers, as well as obstacles perceived by MSMEs and consumers are signal problems that unstable in remote places. But with a variety of information that is easily accessible and ease of use of existing application systems will facilitate the application of digital MSME technology.

\section{b. Organizational}

The context of organizational refers to characteristics, processes, structures and resources that facilitate and limit the adoption of technological innovations. There are three innovation factors that are most often studied in the organizational innovation literature [26], including:

\section{Quality of Human Resources}

The quality of human resources that observe the extent of technical knowledge available in a company [26]. With the application of digital technology, MSMEs are required to be literate in digital technology. Therefore the economic potential of MSMEs can be utilized to the maximum extent as possible.

\section{Top Management Support}

Top management support refers to the role of executive leadership in facilitating and encouraging an overall strategy for the adoption of innovation in the company [26]. In this aspect, MSMEs and consumers feel that there are new innovations in many aspects, both from the aspect of supply of goods, selection of goods, payment, and faster in delivery of goods.

\section{Organizational Size}

Organizational size refers to the size of the company in the ease of technological innovation within the company. Large companies tend to be more complicated in bureaucratic matters and less flexible corporate structures, therefore more difficulties in implementing and accepting technological innovations [28]. This is inversely proportional to MSMEs, which are small companies that tend to facilitate the use of change because of a simpler bureaucracy and a more flexible structure.

\section{c. Environmental.}

Two of the three categories of factors in an environmental context include [5]:

\section{Industry Characteristics}

Mechanical characteristics are the level of pressure perceived by the company from competitors in the industry [29], which consists of competitive pressure and trading partner pressure [26]. MSME competitive pressure arises when MSMEs desire to maintain the 
company's competitive advantage, thus forcing MSMEs to adopt new technologies as an alternative to the strategies they are currently using. More and more MSMEs using digital technology, this will pressure other MSMEs to participate in implementing digital technology; therefore they can compete with other MSMEs. Besides, the application of digital technology can be encouraged by MSME trading partners. For example, a supplier of raw materials for an MSME applies digital technology and this forces the MSME to adopt digital technology in ordering and shipping goods.

\section{Regulatory Support}

Regulatory support is an important environmental factor that influences the adoption of technological innovations in TOE [30]. Government policies can motivate and also inhibit MSMEs in adopting technological innovations. When the government imposes a tax on eCommerce transactions, it will hamper the application of digital technology to MSMEs. Besides, policies that are less flexible towards the e-Commerce business scheme, weak infrastructure development, difficulty in applying for capital loans because there are still many MSMEs that do not yet have a transparent legal entity can also hamper MSME technology innovation. While supporting policies such as financial support, ease of lending, easing loan interest, and tax cuts in e-Commerce transactions will encourage MSMEs to use digital technology.

\section{Conclusion}

The development of the concept of digital technology in Indonesia developed very rapidly during a pandemic like now. Government policies that encourage people to stay at home and carry out activities from home change consumer spending patterns to digital. This has the potential to benefit MSME businesses. MSMEs actors must innovate by applying digital technology, making it easier for companies to develop and introduce their products. Also, from the consumer side, there are also many benefits derived from the application of digital technology. and applicable solutions amid the COVID-19 Pandemic. These aspects need to be considered in developing digital technology in a better and broader MSME business.

\section{Acknowledgements}

The author would like to thank the academics at IAIN Salatiga, especially at the Islamic Economics and Business Faculty of IAIN Salatiga, as well as to all those who supported this research.

\section{References}

[1] Y. R. Suci, "Perkembangan UMKM (Usaha Mikro Kecil dan Menengah) di Indonesia," J. Cano Ekon., vol. 6, no. 1, pp. 51-58, Mar. 2017, doi: 10.30606/CE.V6I1.1239.

[2] Oecd, "Promoting SMEs for Development," 2nd OECD Conf. Minist. RESPONSIBLE SMALL Medium. Enterp., no. June, pp. 1-59, 2004.

[3] "PERKEMBANGAN DATA USAHA MIKRO, KECIL, MENENGAH (UMKM) DAN USAHA 
BESAR (U," 2018.

[4] N. Wulansari, Wahyu, and Y. Kurniawan, "Akselerasi pertumbuhan ekonomi melalui sinergi UMKM dan Good Governance di Indonesia," Pros. Semin. Nas. dan Call Pap. Ekon. dan Bisnis, vol. 2017, pp. 262-268, 2017, doi: 10.1002/anie.201710866.

[5] S. Larsson, "Marketing Innovation for SMEs during COVID-19 Pandemic," 2020.

[6] C. A. Darbonnens and M. Zurawska, Effective Crisis and Emergency Responses in the Multinational Corporation. 2017.

[7] T. Papadopoulos, K. N. Baltas, and M. E. Balta, "The use of digital technologies by small and medium enterprises during COVID-19: Implications for theory and practice," Int. J. Inf. Manage., no. June, p. 102192, 2020, doi: 10.1016/j.ijinfomgt.2020.102192.

[8] D. P, "Entrepreneurial opportunities and the entrepreneurship nexus : re Conceptualization," $J$. Bussines Ventur., vol. 30 (5), pp. 674-695, 2015.

[9] M. Cucculelli and V. Peruzzi, "Innovation over the industry life-cycle. Does ownership matter?," Res. Policy, vol. 49, no. 1, p. 103878, 2020, DOI: 10.1016/j.respol.2019.103878.

[10] Winarsih, M. Indriastuti, and K. Fuad, Impact of COVID-19 on digital transformation and sustainability in small and medium enterprises (SMEs): a conceptual framework, vol. 1194 AISC. Springer International Publishing, 2021.

[11] N. Yadav, K. Gupta, L. Rani, and D. Rawat, "Drivers of Sustainability Practices and SMEs: A Systematic Literature Review,” Eur. J. Sustain. Dev., vol. 7, no. 4, pp. 531-544, 2018, DOI: 10.14207/ejsd.2018.v7n4p531.

[12] H. O. Awa, O. U. Ojiabo, and B. C. Emecheta, "Integrating TAM, TPB and TOE frameworks and expanding their characteristic constructs for e-commerce adoption by SMEs," J. Sci. Technol. Policy Manag., vol. 6, no. 1, pp. 76-94, 2015, DOI: 10.1108/JSTPM-04-2014-0012.

[13] F. T, "Factors influencing ERP outcomes in SMEs: a post-introduction assessment," J. Enterp. Inf. Manag., vol. 22, pp. 81-98, 2009.

[14] A. Scuola, "SMEs' e-commerce adoption: Perspectives from Denmark and Australia," J. Enterp. Inf. Manag., vol. 22, no. 1-2, pp. 152-166, 2009, DOI: 10.1108/17410390910932803.

[15] T. Oliveira and M. F. Martins, "Information technology adoption models at Firm Level," Electron. J. Inf. Syst. Eval., vol. 14, no. 1, pp. 110-121, 2011.

[16] J. Eveland and L. G. Tornatzky, "Technological Innovation as a Process," 1990, pp. 27-50.

[17] P. Y. K. Chau, K. Y. Tam, and K. Y. Tam, "Factors Affecting the Adoption of Open Systems : An Exploratory," MIS Q., vol. 21, no. 1, pp. 1-24, 2014.

[18] I. Rodríguez-Ardura and A. Meseguer-Artola, "Toward a longitudinal model of e-commerce: Environmental, technological, and organizational drivers of B2C adoption," Inf. Soc., vol. 26, no. 3, pp. 209-227, 2010, DOI: 10.1080/01972241003712264.

[19] B. Ramdani, D. Chevers, and D. A. Williams, "SMEs' adoption of enterprise applications: A technology-organization-environment model," J. Small Bus. Enter. Dev., vol. 20, no. 4, pp. 735753, 2013, DOI: 10.1108/JSBED-12-2011-0035.

[20] G. Premkumar, "Adoption of new information technologies in small businesses," Proc. - Annu. Meet. Decis. Sci. Inst., vol. 2, pp. 859-861, 1996.

[21] E. M. Rogers, Diffusion of Innovations, 3rd ed. New York: Free Press, 1989.

[22] C. Markus, M.L. and Tanis, "The enterprise system experience - from adoption to success", in Zmud, R.W. (Ed.)," Fram. Domain IT Manag. Proj., pp. 173-207., 2000.

[23] J. Y. . Thong, “"An integrated model of information systems adoption in small businesses, " $J$. Manag. Inf. Syst., vol. Vol. 15 No, pp. 187-214, 1999.

[24] V. Grover and M. D. Goslar, "The initiation, adoption, and implementation of telecommunications technologies in U.S. organizations," J. Manag. Inf. Syst., vol. 10, no. 1, pp. 141-163, 1993, DOI: 10.1080/07421222.1993.11517994.

[25] K. Zhu, K. Kraemer, and S. Xu, "Electronic business adoption by European firms: A crosscountry assessment of the facilitators and inhibitors," Eur. J. Inf. Syst., vol. 12, no. 4, pp. 251268, 2003, DOI: 10.1057/palgrave.ejis.3000475.

[26] J. L. L. Chong and K. Olesen, "A technology-organization-environment perspective on ecoeffectiveness: A meta-analysis," Australas. J. Inf. Syst., vol. 21, pp. 1-26, 2017, DOI: 
10.3127/ajis.v21i0.1441.

[27] D. Sonnenwald, K. Maglaughlin, and M. Whitton Using Innovation Diffusion Theory to Guide Collaboration Technology Evaluation: Work in Progress. 2001.

[28] F. Damanpour, "An Integration of Research Findings of Effects of Firm Size and Market Competition on Product and Process Innovations," Br. J. Manag., vol. 21, Nov. 2010, DOI: 10.1111/j.1467-8551.2009.00628.x.

[29] K. Zhu and K. L. Kraemer, "Post-adoption variations in usage and value of e-business by organizations: Cross-country evidence from the retail industry," Inf. Syst. Res., vol. 16, no. 1, pp. 61-84, 2005, DOI: 10.1287/isre.1050.0045.

[30] J. Gibbs, K. L. Kraemer, and J. Dedrick, "Environment and Policy Factors Shaping Global ECommerce Diffusion: A Cross-Country Comparison," Inf. Soc., vol. 19, no. 1, pp. 5-18, Jan. 2003, DOI: 10.1080/01972240309472. 